\title{
Pengaruh Kompetensi, Profesionalisme, Beban Kerja, Pengalama Auditor Terhadap Kemampuan Auditor Dalam Mendeteksi Kecurangan
}

\author{
Chelli Resgi Arnanda 1), Varon Diaz Purba ${ }^{2)}$, Arie Pratania Putri ${ }^{3)}$ \\ 1), 2), 3) Universitas Prima Indonesia, Medan, Indonesia \\ arieprataniaputri@unprimdn.ac.id
}

*Penulis Korespondensi

Diajukan : 1 Januari 2022

Disetujui : 10 Januari 2022

Dipublikasi : 15 Januari 2022

\begin{abstract}
study aims to examine the effect of competence, professionalism, workload and auditor experience on the auditor's ability to detect fraud. This research uses descriptive research method with quantitative approach and causal comparative type. The population of this research is all auditors who work in the Public Accounting Firm in Medan City. The research sample was drawn using purposive sampling method and obtained 65 samples. This study uses multiple linear regression analysis which is used to test whether the independent variable has an effect on the dependent variable. Data analysis for hypothesis testing was carried out with Statistical Product and Service Solutions (SPSS) ver. 25. The results of the regression test (t-test) show that only the experience variable has a positive effect on the auditor's ability to detect fraud. The choice of place to conduct research is based on the need for the latest information about the effect of competence, professionalism, workload and auditor experience on the auditor's ability to detect fraud at the Public Accounting Firm in Medan City.
\end{abstract}

Keywords: Competence, Professionalism, Workload, Auditor Experience, and Auditor Ability to Detect Fraud

\section{PENDAHULUAN}

Kantor Akuntan Publik (KAP) adalah organisasi yang sudah diberi izin oleh kementerian keuangan untuk menjadi tempat para akuntan menjual jasanya. Kemampuan auditor dalam mendeteksi kecurangan adalah kehandalan yang harus dimiliki auditor agar dapat menyatakani adanya ketidawajaran dalam sebuahi laporan keuangan dan menunjukkan bukti bukti dari kecurangan tersebut. Faktor-faktor yang mempengaruhi kemampuan auditor dalam mendeteksi kecurangan antarai lain adalah sikap kompetensi, profesionalisme, beban kerjaidan pengalaman kerja.

Untuk mencapai kualitasiaudit yang baik seorarang auditor harus milikiki sikap kompeten. Dimana kompetensi auditor berarti dengan segala kemamapuan yang ia miliki auditor diharapkan mampu melakukan pengauditan dengan cermat dan teliti. Seorang auditor juga harus memiliki kecakapan yang tinggi agar mampu mendeteksi dan mengumpulkan bukti-bukti yang valid jika di dalam suatu laporan keuangan terdapat sebuah kecurangan. 
Selain memiliki sikap kompeten, seorang auditor juga harus memiliki sikap profesional. Seorang auditor bisa dikatakan profesional jika sudah melaksanakan pendidikan profesi yang menjadikannya memiliki keahlian dan kategori khusus. Profesional adalahi kata sifat. Profesional adalah satu kepatuhan auditor terhadap kode etik profesinya. Profesional adalah sikap perseorangan, hal ini yang menjadikan pembeda antara auditor yang satu dengan auditor lainnya. Dengan memiliki sikap profesional yang tinggi diharapkan seorang auditor dapat mendeteksi segala bentuk kecurangan yang terjadi dengan seksama.

Didalam melakukan pemeriksaan laporan keuangan, auditor dituntut untuk mengerjakannya dengan cepat dan tepat. laporan keuangan yang harus diperiksa auditor biasanya tidak hanyak 1 atau 2. Oleh karena itu biasanya auditor memiliki beban kerja yang sangat banyak. Beban kerja adalah pekerjaan yang harus dilakukan auditor dalam jangka waktu yang telah ditentukan. Banyaknya beban kerja biasanya menajadikan auditor kelelahan dan kurang teliti dalam melakukan pemeriksaan dan mendeteksi kecurangan. Namun biasanya beban kerja yang banyak menjadikan auditor lebih berpengalaman dalam melakukan pengauditan.

Semakin tinggi jam kerja seorang auditor biasanya berbanding lurus dengan pengalaman yang dimiliki. Pengalaman auditor akan menjadikan auditor lebih mahir dalam mendeteksi kecurangan yang terjadi, hal ini dikarenakan auditor terbiasa dengan sinyal sinyal kecurangan yang pernah ia temukan didalam laporan keuangan yang sebelumnya pernah ia periksa. Salah satu kasus kecuranganiyang terjadi adalah kasus PT GARUDA yang terkena sanksi dari Otoritas Jasa Keuangan (OJK), Kemsenteriani Keuangan dan Bursa Efek Indonesia (BEI). Semua bermula dari hasil pembukuan laba bersih 2018 yangi melonjak tajam dibandingkan tahun 2017 Sekretaris Jenderal Kemenkeum Hadiyanto menyatakan, berdasarkan hasil pertemuan dengan pihak KAP disimpulkan adanya dugaan audit yang tidak sesuai dengan standar akuntansi. Akuntan Publik (AP) Kasnerm Sirumapea dan Kantor Akuntan Publikl(KAP)I Tanubratafa, Sutanto, Fahmisad, Bambang dan Rekan yang merupakan auditor laporan keuangan PT Garuda di tahun 2018 diketahui melanggar kode etik profesi auditor karena tidak memiliki sikapi profesional saat menjalankan tugasnya. Setelah melakukan pemeriksaan dan menemukan adanyai kecurangan, auditor-auditor tersebut tidak melaporkannya kepada pihak yang berwenang dan menyebabkan mereka divonis 12 bulan pembekuan izin (sumber:https://economy.okezone.com/read/2019/06/28/320/2072245/ikronologikasuslaporankeuangan-garuda-indonesia-hingga-kena-sanksi?page=3).

\section{STUDI LITERATUR}

Pengaruh Kompetensi Terhadap Kemampuan Audior dalam Mendeteksi Kecurangan

Pengertian kompetensi menurut Suparno $(2012,27)$ adalah kemampuan dan keahlian yang dimiliki seorang auditor untuk melakukan pekerjaannya. Semakin tinggi kemampuan dan keahlian seorang auditor maka akan berpengaruh dalam tanggung jawab auditor mendeteksi kecurangan. Opini yang diberikan oleh auditor untuk menentukan hasil audit sangat dipengaruhi oleh kemampuan dan keahlian yang merupakan unsur dari kompetensi. (Ramadhany, 2015).

\section{Pengaruh Profesionalisme Terhadap Kemampuan Auditor dalam Mendeteksi Kecurangan}

Menurut karamoy et all (2015) profesionalisme yang dimiliki auditor sejalan dengan kehandalan auditor dalam menemukan kecurangan yang terjadi. Dalam melaksanakan dan 
membuat laporan hasil pemeriksaan, audior dituntut untuk menggunakan kemahiran profesionalnya secara cermat. Dengan keprofesionalan yang dimilikinya, auditor akan mampu menentukan jenis pemeriksaan, meteodologi yang digunakan, menentukan dan mengumpulkan bukti bukti kecurangan serta menentukan prosedur pemeriksaan.

\section{Pengaruh Beban Kerja Terhadap Kemampuan Auditor dalam Mendeteksi Kecurangan}

Munandar $(2014,20)$ menjelaskan bahwa Beban kerja merupakan kewajiban yang dibebankan ke pegawai yang ahli dibidangnya untuk diselesaikan tepat waktu dengan menggunakan keterampilan dan potensi yang dimiliki. Beban kerja adalah sejumlah urusan yang harus diselesaikan oleh kelompok dalam jangka waktu tertentu (Siswanto dalam Nova Ellyzar, 2017:38). Setiawan dan Fitriany (2011) mengatakan bahwa tingginya beban kerja akan mengakibatkan kelelahan pada aditor dan menurunkan keteletiannya dalam mendeteksi kecurangan.

\section{Pengaruhf Pengalaman Auditor Terhadap Kemampuan Auditor dalam Mendeteksi Kecurangan}

Menurut Nasution (2012) Pengalaman adalah kehandalan yang didapatkan melalui sebuah kejadian, observasi maupun dengan terlibat langsung di kejadian tersebut. Bawono dan Singgih (2011) menyatakan jika kegiatan dilakukan secara berulang akan menjadi salah satu hal penyebab meningkatkan pengalaman serta membuat auditor lebih handal dalam menyelesaikan tugas-tugas dan mendeteksi jika terdapat suatu kecurangan.

\section{Kerangka konseptual}

Dalam penelitian ini, kerangka konseptual digunakan untuk menjelaskan keterkaitan antara pengaruh kompetensi, profesionalisme, beban kerja dan pengalaman auditor terhadap kemampuan auditor dalam mendeteksi kecurangan (fraud) secara singkat, padat dan jelas. Kerangka konseptual dibuat berupa bagan yang ditujukan untuk menjelaskan hubungan variabel independen dengan variabel dependen.

Berdasarkan uraian diatas, kerangka konseptual yang digambarkan berikut:

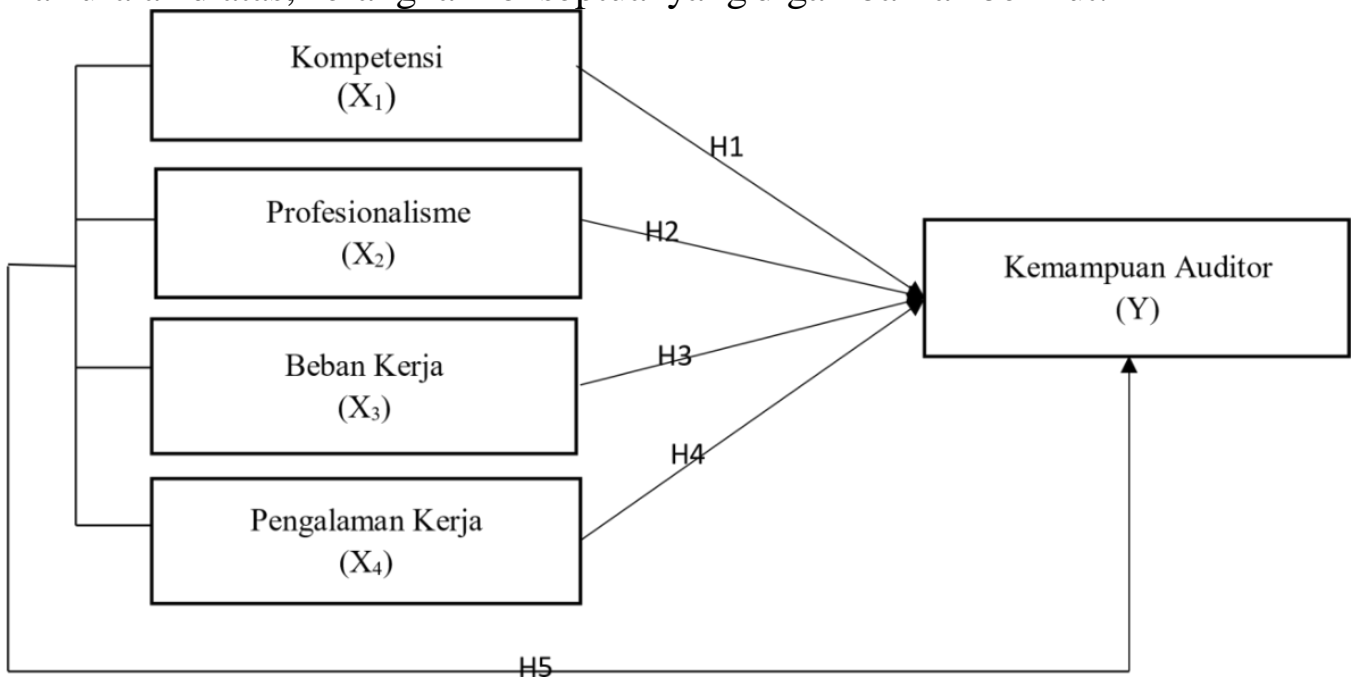

H1: Adanya pengaruh kompetensi terhadap kemampuan auditor dalam mendeteksi kecurangan 
(Fraud)

H2: Adanya pengaruh profesionalisme terhadap kemampuan auditor dalam mendeteksi kecurangan (Fraud)

H3: Adanya pengaruh beban kerja terhadap kemampuan auditor dalam mendeteksi kecurangan (Fraud)

H4: Adanya pengaruh pengalaman kerja terhadap kemampuan auditor dalam mendeteksil kecurangan (Fraud)

H5: Adanya pengaruh kompetensi, profesionalisme, beban kerja, dan pengalaman auditor terhadapkemampuan auditor dalam mendeteksi kecurangan (Fraud)

\section{Jenis, Pendekatan dan Sifat penelitian}

\section{METODE}

Deskriftif adalah jenis dari penelitian ini. Tersian (2018:19) menyatakan bahwa penelitian ini digunakan untuk mengetahui nilai variabel tak terikat tanpa membandingkannya dengan variabel lain. Pendekatan penelitian yangi dipakai ialah pendekatan kuantitatif. Menurut Sugiyono (2015:8) metode penelitian kuantitatif adalah sebuah metode yang didasari oleh filsafat positivisme, yang dipergunakan untuk meneliti suatu sampel tertentu. Jenis penelitian ini adalah kausal komparative. Kausal komparatif adalah suatu penelitianuntuk membandingkan variabel antara subjek yang berbedadan mencari hubungan sebab akibatnya (Paramita dan Rizal, 2019:14)

\section{Populasi}

Menurut Paramita Rizal (2019:59) penyatuan antara sesuatu yang memiliki ciri khas tersendiri serta dijadikan titik pusat penelitian disebut populasi. Populasi penelitian ini adalah 22 Kantor Akuntan Publik di Kota Medan.

\section{Sampel}

Menurut Tersiana (2018:77) elemen yang terdapat didalam populasi serta digunakan untuk pengujian dan hasilnya merupakan kesimpulan dari populasi disebut sampel. Pengambilan sampel dalam penelitian ini menggunakan metode purposive sampling. Menurut Sugiyono (2017) purposive sampling merupakan penarikan sampel data yang mempergunakan kriteria tertetu. Kriteria tersebut berupa:

1. KAP yang berada di Kota Medan

2. KAP yang bersedia untuk diriset

3. KAP yang memiliki nomor izin usaha

4. KAP yang memiliki paling sedikit dua auditor

Daftar Nama KAP yang Sesuai dengan Kriteria :

1. KAP Syamsul Bahri

2. KAP Laksmono

3. KAP Tarmizi Taher

4. KAP Armandias Jakarta Cabang Medan

5. KAP Khairul

6. KAP Liasta, Nirwan, Syafruddin \& Rekan

7. KAP Fachrudin \& Mahyuddin

8. KAP M.Lian Dalimunthe \& Rekan 
9. KAP Selamat Sinuraya

\section{Definisi Operasional}

Definisi operasional variable penelitian menurut Sugiyono $(2015,38)$ adalah suatu hal yang memiliki variasi tertentu yang sudah ditentukan peneliti untuk kemudian ditarik kesimpulannya.

\begin{tabular}{|c|c|c|c|}
\hline No & Variabel & Indikator & Skala \\
\hline 1 & $\mathrm{X} 1$ & $\begin{array}{ll}\text { 1. Pengetahuan } \\
\text { 2. Keahlian } \\
\text { 3. Sikap }\end{array}$ & Likert \\
\hline 2 & $\mathrm{X} 2$ & $\begin{array}{ll}\text { 1. } & \text { Pengabdian Sosial } \\
\text { 2. } & \text { Kewajiban } \\
\text { 3. } & \text { Kemandirian } \\
\text { 4. } & \text { Keyakinan Terhadap Profesi } \\
\text { 5. } & \text { Hubungan antar Profesi (Ratna, 2012:34) }\end{array}$ & Likert \\
\hline 3 & X3 & $\begin{array}{l}\text { 1. Target yang harus dicapai } \\
\text { 2. Kondisi Pekerjaan } \\
\text { 3. Standart Pekerjaan, merupakan indikator } \\
\text { beban kerja (Putra 2012:22) }\end{array}$ & Likert \\
\hline 4 & $\mathrm{X} 4$ & $\begin{array}{l}\text { 1. Lama Waktu Kerja dibidang Audit } \\
\text { 2. Tingkat Penguasaan Audit } \\
\text { 3. Jenis Perusahaan yang di audit adalah } \\
\text { indikator pengalaman (Ismayanti, 2012) }\end{array}$ & Likert \\
\hline 5 & $\mathrm{Y}$ & $\begin{array}{l}\text { 1. Pengetahuan tentang Kecurangan } \\
\text { 2. Kesanggupan dalam tahap Pendeteksian } \\
\text { 3. Pendeteksian Kecurangan (Pramudiastuti, } \\
\text { 2014) }\end{array}$ & Likert \\
\hline
\end{tabular}

\section{Jenis Data}

Jenis data yang dipergunakan penelitian adalah data primer dan data sekunder. Datai primer adalah data yang di dapat dengan cara menyebarkani angket kepadai respondeni dani jawaban sistematis dari reponden tersebut lah yang disebut sebagai data primer (sugiyono : 2018,213). Data sekunder adalah data yang melengkapi data primer seperti bukui dan penelitiani sebelumnya (Sugiyono, 2017:137).

\section{Analisis Data}

Metode analisis data menggunakan sebuah program bernama Statistical Productand Service Solution (SPSS) dan menggunakan analisis regresi berganda dengan rumus :

$\mathbf{Y}=\mathbf{a}+\mathbf{b}_{1}$ Kompetensi $+\mathbf{b}_{2}$ Profesionalisme $-\mathbf{b}_{3}$ Beban Kerja $+\mathbf{b}_{4}$ Pengalaman Auditor $+\mathbf{e}$

Keterangan:

$\mathrm{Y}=$ Kemampuan auditior dalam mendeteksi kecurangan

$\mathrm{a}=$ Konstanta 
$\mathrm{b}=$ Koefesien regresi berganda

$\mathrm{e}=$ Standart error

$\mathrm{X} 1=$ Kompetensii

$\mathrm{X} 2=$ Profesional

$\mathrm{X}_{3}=$ Beban Kerja

X4 = Pengalaman Auditor

\section{Uji Kualitas Data Uji Validitas}

Valid tidaknya suatu kuesioner atau angket dapat diketahui dengan melakukan uji validitas. Sebuah valid apabila pernyataan pada kuesioner tersebut dapat menyajikan sesuatu yang dapat diukur (2013:202). Data dikatakan valid jika r hitungi > r table.

\section{Uji Reliabilitas}

Untuk memperoleh output penelitian yang absah dan teruji serta dapat dipakai menaksir lebih dari sekali agar memberikan hasil data yang kukuh adalah fungsi dari uji reliabilitas. Data dapat dikatakan reliabel jika nilai Croncbach's Alpha >1 0,6.

\section{Uji Asumsi Klasiki}

\section{Ujii Normalitas Residual}

Ghozali (2011:160) menyatakani bahwa uji normalitas digunakan untuk menguji kenormalan variabel pengganggu di sebuah model regresi. Pemilihan standart dengan pengujian ini adalah: Asymp. Sig $<$ i $0.05=$ Distribusi Tidak Normal. Asymp. Sig $>0.05$ Distribusi Normal.

\section{Uji Multikolinearitas}

Uji Multikonolinearitas dipakai untuki dapat mengetahui apakah ada kolerasi antara vaiabel independen atau tidak dalam suatui model regresi. Ghozali (2011: 105). Menurut Imam Ghozali (2013) syarat regresi bisa terbebasi dari gejala ini adalah ketika nilai tolerance $>0$, dan Variance Inflation Facto (VIF) < 10.

\section{Uji Heteroskedastisitas}

Uji Heteroskastisitas dipakai dalam sebuah regresi untuk menguji apakah terjadi ketidaksamaan varian dari residual yang terdapat pada pengamatan lain.

\section{Uji F dan Uji T}

Uji F dilakukan untuk mengetahui pengaruh antara variable bebas denganvariabel terikat secara bersamai sama menggunakan F hitung (Danang Sunyoto 2013:137). Menurut Sugiyono (2018;223). Uji T merupakan hipotesis dari rumusan masalah, yaitu yang meminta hubungan antara dua atau lebih variabel.

\section{HASIL}

Sebanyak 125 kuesioner disebarkan pada 22 Kantor Akuntan Publik yang berada di Kota 
Medan. Dari 125 kuesioner tersebut, hanya 65 kuesioner (52\%) yang kembali dan dapat diolah sementara sisanya sebanyak 60 kuesioner (48\%) tidak kembali dan tidak dapat diolah.

Tabel 1.

\begin{tabular}{|c|c|c|}
\hline No. & Keterangan & Persentase (\%) \\
\hline $\mathbf{1 .}$ & Jenis Kelamin & $\mathbf{1 0 0 \%}$ \\
\hline & Laki-laki & $61,5 \%$ \\
\hline & Perempuan & $38,5 \%$ \\
\hline $\mathbf{2 .}$ & Usia & $\mathbf{1 0 0 \%}$ \\
\hline & $22-27$ tahun & $30,8 \%$ \\
\hline & $27-32$ tahun & $33,8 \%$ \\
\hline & $>32$ tahun & $35,4 \%$ \\
\hline 3. & Pendidikan Terakhir & $\mathbf{1 0 0 \%}$ \\
\hline & S1 & $100 \%$ \\
\hline & S2 & - \\
\hline & S3 & - \\
\hline
\end{tabular}

\section{Uji Deskriptif Statistik}

Dibawah ini disajikan data statistik secara umum dari keseluruh data sampel penelitian pada Kantor Akuntan Publik yang berada di Kota Medan.

Tabel 2.

\begin{tabular}{|l|c|c|c|c|l|}
\hline & $\mathrm{N}$ & Min & Max & Mean & S.Deviation \\
\hline Kompetensi & 65 & 19 & 30 & 25.65 & 2.695 \\
\hline Profesionalisme & 65 & 35 & 50 & 43.09 & 3.399 \\
\hline Bebab Kerja & 65 & 20 & 30 & 24.69 & 2.555 \\
\hline Pengalaman & 65 & 20 & 30 & 25.05 & 1.907 \\
\hline $\begin{array}{l}\text { Kemampuan Auditor } \\
\text { dalam } \\
\text { Kecurangan }\end{array}$ & 65 & 22 & 28 & 24.89 & 1.706 \\
\hline $\begin{array}{l}\text { Valid N (listwise) } \\
\text { Mendeteksi }\end{array}$ & 65 & & & & \\
\hline
\end{tabular}

1. Dari sampel data Kompetensi dengan nilai minimum yang diperoleh adalah 19 dan nilai maksimum yang diperoleh adalah 30 sedangkan rata-rata (mean) yang diperoleh adalah 25.65 dengan standar deviasi yang diperoleh adalah 2.695.

2. Dari 65 sampel data Profesionalisme dengan nilai minimum yang diperoleh adalah 35 dan nilai maksimum yang diperoleh adalah 50 sedangkan rata-rata yang diperoleh adalah (mean) 43.09 dengan standar deviasi yang diperoleh adalah 3.399.

3. Dari 65 sampel data Beban Kerja dengan nilai minimum yang diperoleh adalah 20 dan nilai maksimum yang diperoleh adalah 30 sedangkan rata-rata (mean) yang diperoleh adalah 24.69 dengan standar deviasi yang diperoleh adalah 2.555 .

4. Dari 65 sampel data Pengalaman dengan nilai minimum yang diperoleh adalah 20 dan nilai maksimum yang diperoleh adalah 30 sedangkan rata-rata (mean) yang diperoleh adalah 25.05 
dengan standar deviasi yang diperoleh adalah 1.907.

5. Dari 65 sampel data Beban Kerja dengan nilai minimum yang diperoleh adalah 22 dan nilai maksimum yang diperoleh adalah 28 sedangkan rata-rata (mean) yang diperoleh adalah 24.89 dengan standar deviasi yang diperoleh adalah 1.706.

\section{Uji Kualitas Data}

\section{Tabel 3. Uji Validitas}

\begin{tabular}{|l|c|c|c|}
\hline \multicolumn{1}{|c|}{ Variabel } & R Hitung & R Tabel & Keterangan \\
\hline Kompetensi & 0,616 & 0,2441 & Valid 1 \\
\hline Profesionalise & 0,715 & 0,2441 & Valid 1 \\
\hline Beban Kerja & 0,498 & 0,2441 & Valid 1 \\
\hline $\begin{array}{l}\text { Pengalaman Auditor dalam } \\
\text { Kemampuan Aundeksi Kecurangan }\end{array}$ & 0,718 & 0,2441 & Valid 1 \\
\hline Mendeteks5 & 0,2441 & Valid 1 \\
\hline
\end{tabular}

Setelah peneliti melakukan pengujian maka didapati bahwa hasil diatas valid dikarenakan $r$ hitung lebih besar daripada r-tabel.

Tabel 4. Uji Reliabilitas

\begin{tabular}{|l|c|c|}
\hline \multicolumn{1}{|c|}{ Variabel } & Cronbach's Alpha & Keterangan \\
\hline Kompetensi & 0,669 & Reliabel \\
\hline Profesionalise & 0,759 & Reliabel \\
\hline Beban Kerja & 0,691 & Reliabel \\
\hline Pengalaman Auditor dalam & 0,798 & Reliabel \\
\hline $\begin{array}{l}\text { Kemampuan } \\
\text { Mendeteksi Kecurangan }\end{array}$ & 0,742 & Reliabel \\
\hline
\end{tabular}

Setelah peneliti melakukan pengujian yang berulang maka didapati bahwa data diatas reliabel dikarenakan koefisien alpha lebih besar dari r-tabel.

\section{Uji Asumsi Klasik}

Tabel 5. Uji Normalitas One-Sample Kolmogorov-Smirnov Test
Asymp. Sig. (2-tailed)
0.058

Pada tabel III.5 terlihat nilai asymp. Sig. (2-tailed) sebesar 0,058 yang artinya nilai tersebut diatasi nilai signifikan 5\% $(0,05)$, itu berarti bahwa variabel residual berdistribusi normal.

Tabel 6. Uji Multikolinearitas

\begin{tabular}{|c|c|c|}
\hline Variabel & Tolerance & VIF \\
\hline Kompetensi & 0.484 & 2.064 \\
\hline Profesionalitas & 0.484 & 2.068 \\
\hline Beban Kerja & 0.500 & 2.000 \\
\hline Pengalaman & 0.929 & 1.077 \\
\hline
\end{tabular}


Berdasarkan tabel III.6 diatas, nilai tolerance value semua variabel independen berada di atas 0,10 yaitu sebesar 0,484 untuk Kompetensi sebagai X1; 0,484 untuk Profesionalisme sebagai X2; 0,500i untuk Beban Kerja sebagai X3, dan 0,929 untuk Pengalaman sebagai X4. Sedangkan nilai VIF antara variabel $\mathrm{X} 1, \mathrm{X} 2, \mathrm{X} 3$, dan X4 berada dibawah 10. Sehingga dapat disimpulkan berdasarkan nilai tolerence dan VIF bahwa pada penelitian ini tidak terjadi Multikolonieritas.

Tabel 7. Uji Heteroskedastisitas

\begin{tabular}{|c|c|}
\hline Variabel & Sig \\
\hline Konstant & 0.901 \\
\hline Kompetensi & 0.799 \\
\hline Profesionalisme & 0.726 \\
\hline Beban Kerja & 0.642 \\
\hline Pengalaman Auditor & 0.647 \\
\hline
\end{tabular}

Daritabel 7. dapat dilihat bahwa nilai signifikan seluruh variabel bebas $>0,05$ artinya pada penelitian ini model regresi tidak mengalami masalah heteroskedastisitas.

\section{Hasil Analisis Data}

Tabel 8. Uji Regresi Linier Berganda

\begin{tabular}{|c|c|}
\hline Variabel & B \\
\hline Konstant & 8.668 \\
\hline Kompetensi & 0.010 \\
\hline Profesionalisme & 0.058 \\
\hline Beban Kerja & -0.050 \\
\hline Pengalaman Auditor & 0.595 \\
\hline
\end{tabular}

1. Berdasarkan dari tabel III.8 nilai konstanta sebesar 8.668, hal itu bermakna bahwa variabel kompetensi, profesionalisme, beban kerja dan pengalaman dianggap konstan.

2. Nilai koefisien kompetensi (X1) ialah sebesar 0,010. Ini berarti jika kompetensi mengalami peningkatan $1 \%$, maka kemampuan auditor dalam mendeteksi kecurangan akan mengalami penurunan sebesar $0,010 \%$.

3. Nilai koefisien profesionalisme (X2) ialah sebesar 0,058. Ini berarti jika profesionalisme mengalami peningkatan Rp. 1\%, maka kemampuan auditor akan mengalami penurunan sebesar $0,058 \%$.

4. Nilaimkoefisien beban kerja (X3) ialah sebesar -0,050. Ini berarti jika beban kerja mengalami peningkatan $1 \%$, maka kemampuan auditor dalam mendeteksi kecurangan akan mengalami penurunan sebesar $0,050 \%$.

5. Nilai koefisien pengalaman (X4) ialah sebesar 0,595. Ini berarti jika pengalaman mengalami peningkatan $1 \%$, maka kemampuan auditor dalam mendeteksi kecurangan akan mengalami peningkatan sebesar $0,595 \%$. 


\section{Uji T dan Uji F}

\section{Uji T}

1. Secara parsial uji t untuk Kompetensi terhadap kemampuan auditor dalam mendeteksi kecurangan adalah nilai t hitung 0,070 sedangkan nilai t tabel sebesar 2,04227. Maka 0,070 < 2,04227 dengan nilai signifikan 0,945>0,05, maka secara parsial Kompetensi tidak berpengaruh secara signifikan terhadap kemampuanauditor dalam mendeteksi kecurangan.

2. Secara parsial uji t untuk Profesionalisme terhadap kemampuan auditor dalam mendeteksi kecurangan adalah nilai t hitung 0,480 sedangkan nilai $t$ tabel sebesar 2,04227. Maka 0,480 < 2,04227 dengan nilai signifikan 0,635>0,05, maka secara parsial profesionalisme tidak berpengaruh secara signifikan terhadap kemampuan auditor dalam mendeteksi kecurangan.

3. Secara parsial uji $\mathrm{t}$ untuk beban kerja terhadap kemampuan auditor dalam mendeteksi kecurangan adalah nilait hitung $-0,077$ sedangkan nilai $t$ tabel sebesar 2,04227. Maka $-0,077$ $<$ i 22,04227 dengan nilai signifikani 0,733> 0,05, maka secara parsial beban kerja tidak berpengaruh secara signifikan terhadap kemampuan auditor dalam mendeteksi kecurangan.

4. Secara parsial uji $\mathrm{t}$ untuk Pengalaman terhadap kemampuan auditor dalam mendeteksi kecurangan adalah nilai t hitung 3,201 sedangkan nilai t tabel sebesar 2,04227. Maka 8,201 > 2 dengan nilai signifikan $0,005<0,05$, maka secaral parsial pengalaman berpengaruh secara signifikan terhadap kemampuan auditordalammendeteksi kecurangan.

Tabel 9. Uji F

\begin{tabular}{|c|c|c|}
\hline Model & F & Sig \\
\hline Regression & 2.456 & 0.067 \\
\hline
\end{tabular}

Dari tabel diatas, dapat dilihat dari nilai signifikan sebesar 0,067 >0,05. Dan diperoleh nilai $\mathrm{F}_{\text {hitung }}$ sebesar 2,456 dengan menggunakan tabel $\mathrm{F}$ ialah $\mathrm{n}-\mathrm{k}=35-5=30$ didapat nilai $\mathrm{F}_{\text {tabel }}$ 2,69. Artinya $2,456<2,69$, sehingga variabel independen pada penelitian ini tidak berpengaruh secara1 simultan terhadap variabel dependen (kemampuan auditor dalam mendeteksi kecurangan).

\section{PEMBAHASAN}

\section{Pengaruh Kompetensi terhadap Kemampuan Auditor dalam Mendeteksi Kecurangan}

Pada penelitian secara parsial kompetensi tidak berpengaruh secara signifikan terhadap kemampuan auditor dalam mendeteksi kecurangandan menolak $\mathrm{H}_{1}$. Hal ini membuktikan bahwa semakini tinggi kompetensi seorang auditor tidak dapat menjamin kemampuannya dalam mendeteksi kecurangan. Hasil ini memperkuat penelitan sebelumnya oleh Didi Atmaja (2016) yang menyatakan bahwa "Seorang auditor yang mempunyai kompetensi tinggi belum tentu menjadi auditor yangi mampu mendeteksi fraud. Hal ini bisa terjadi karena saat ini modus fraud yang dilakukan semakin kompleksi dan canggihi serta menuntut kemampuan yang lebih spesifik lagi dalam mendeteksi fraud tersebut.” Menurut George klemp, dalam Emron, Yohny, Imas (2017) kompetensi merupakan hal yang mendasari seseorang untuk melakukan pekerjaan secara tepat.

Pengaruh Profesionalisme terhadap Kemampuan Auditor dalam Mendeteksi Kecurangan

Hasil penelitian ini menolak $\mathrm{H}_{2}$ yang menyatakan bahwa profesionalisme berpengaruh terhadap kemampuan auditor dalam mendeteksi kecurangan. Hal ini sejalan dengan penelitian sebelumnya yang dilakukan oleh Jesicca dan Partogian (2019) yang menyatakan bahwa "Sikap profesionalisme auditor saat melakukan pemeriksaan belum tentu memampukan auditor dalam 
hal mendeteksi tindakan kecurangan yang terjadi." Menuruti Oerip dan Uetomo (2012:264) profesionalisme merupakan ciri khusus yang harus dimiliki seseorang dalam melaksanakan pekerjaannya.

\section{Pengaruh Beban Kerja terhadap Kemampuan Auditor dalam Mendeteksi Kecurangan}

Hasil penelitian ini menolak $\mathrm{H}_{3}$ yang menyatakan bahwa beban kerja berpengaruh terhadap kemampuan auditor dalam mendeteksi kecurangan. Penelitian ini semakin memperkuat penelitian sebelumnya yang dilakukan oleh Hafifah Nasutiondan Fitriany (2012) yang menyatakan bahwa "Hasil penelitian yang diperoleh menyatakan bahwa beban kerja tidak mempengaruh skeptisisme profesional dan kemampuan auditordalam mendeteksikecurangan, sedangkan pengalaman audit dan tipe kepribadian berpengaruh terhadap skeptisisme profesionaldan kemampuan auditor dalam mendeteksi kecurangan." Munandar $(2014,20)$ menyatakan bahwa beban kerja adalah tugas yang diberikan kepada tenaga kerja untuk diselesaikan sesuai jadwal.

\section{Pengaruh Pengalaman terhadap Kemampuan Auditor dalam Mendeteksi Kecurangan}

Hasil penelitian ini menyatakan bahwa pengalaman berpengaruh terdahap kemampuan auditor dalam mendeteksi kecuragan yang berarti penelitian ini juga menerima $\mathrm{H}_{1}$. Penelitian ini semakin memperkuat penelitian sebelumnya yang dilakukan oleh Bawono dan Singih (2011) yang menyatakan bahwa pekerjan yang secara berulang-ulang dilakukan juga menjadi salah satu hal yang dapat meningkatkan pengalaman dan membuat auditor lebih handal dalam menyelesaikan tugas-tugas dan mendeteksi jika terdapat suatu kecurangan. Menurut Nasution (2012) pengalaman adalah kemampuan yang didapat dari suatu kejadian melalui pengamatan langsung ataupun dengan berpartisipasi langsung dalam peristiwa tersebut.

\section{KESIMPULAN}

Setelah dilakukan penelitian terdapat variabel kompetensi, profesional dan beban kerja tidak berpengaruh secara signifikan terhadap kemampuan auditor dalam mendeteksi kecurangan dengan masing-masing nilai sig adalah 0,$945 ; 0,635 ; 0,733>0,05$. Hanya variabel pengalaman yang memiliki pengaruh secara signifikan terhadap kemampuan auditor dalam mendeteksi kecurangan dengan nilai sig $0,005<0,05$. Uji yang dilakukan secara simultan tidak berpengaruh dikarenakan nilai signifikan diatas 0,05 .

\section{UCAPAN TERIMA KASIH}

Pada kesempatan ini penulis mengucapkan rasa terima kasih dan penghargaan yang setinggi-setingginya kepada yang terhormat Ibu Arie Pratania Putri, S.E., M.Si., Ak, CA., CJAT, sebagai Dosen Pembimbing atas kesudiannya memberikan bantuan dan bimbingan serta arahan untuk menyelesaikan penulisan jurnal ini ditengah-tengah kesibukannya.

\section{REFERENSI}

Cori, C., \& Purnama, L. (2019). Pengaruh Faktor Sumber Daya Manusia Terhadap Kinerja. Jurnal Transaksi, 11(1), 22-30.

Danny, A. I. (2015). Pengaruh Profesionalisme dan Independensi Auditor terhadap Pertimbangan Tingkat Materialitas Salah Saji Laporan Keuangan Instansi Pemerintah (Studi pada Kantor BPKP RI di Jakarta). 2003, 13-69. 


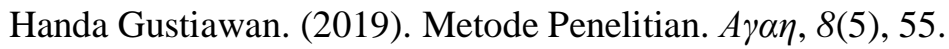

Henani, T. R. P. (2018). Pengaruh Beban Kerja Dan Lingkungan Kerja Terhadap Kinerja Karyawan. Studi Kasus pada PT. Pegadaian (Persero) Cabang Wonosobo. Director, 15(40), 6-13. http://awsassets.wwfnz.panda.org/downloads/earth_summit_2012_v3.pdf\%0A

Herliandry, L. D., Nurhasanah, Suban, M. E., \& Heru, K. (2020). Transformasi Media Pembelajaran Pada Masa Pandemi Covid-19. Jurnal Teknologi Pendidikan, 22(1), 65-70. http://journal.unj.ac.id/unj/index.php/jtp

Irlane Maia De Oliveira. (2017). Pengaruh Beban Kerja, Pengalaman Audit Dan Skeptisisme Profesional Terhadap Kemampuan Auditor Dalam Mendeteksi Kecurangan. (Studi Kasus Pada Kantor Akuntan Publik Di DIY). 1-14.

Karamoy, H., \& Wokas, H. R. N. (1967). Pengaruh Independensi dan Profesionalisme, Dalam Mendeteksi Fraud Pada Auditor Internal Provinsi Sulawesi Utara. Angewandte Chemie International Edition, 6(11), 951- 952.

Kekeliruan, M., \& Dan, E. P. (2016). SKRIPSI Oleh : Nama : Raja Asrubi Eka Putra FAKULTAS EKONOMI.

Korry, D. I. (2017). Pengaruh Status Kerja Ibu Rumah Tangga Terhadap Coping Stress. Repository Unika Sogijapranata, 36-44. http://repository.unika.ac.id/id/eprint/14757

Kualitas Audit Dengan Kualitas Komite Audit Sebagai Variabel Pemoderasi. Jurnal Akuntansi Dan Keuangan Indonesia, 8(1), 36-53. https://doi.org/10.21002/jaki.2011.03

OFFERING (Studi Empiris Perusahaan Go Public yang terdaftar di Bursa Efek Indonesia Tahun 20112015). Nominal, Barometer Riset Akuntansi Dan Manajemen, 7(1). https://doi.org/10.21831/nominal.v7i1.19781.

Oktary, M. E. (2013). Pengaruh Hasil Belajar Produk Kreatif dan Kewirausahaan Terhadap Minat Berwirausaha SMK Immanuel Sungai Raya. 2014, 2-31.

Pustaka, K., Pemikiran, K., \& Hipotesis, D. a N. (2004). Bab II Kajian Pustaka, Kerangka Pemikiran Dan Hipotesis. I, 16-45.

Rahayu, S., \& Gudono. (2016). Faktor-Faktor yang Mempengaruhi Kemampuan Auditor dalam Pendeteksian Kecurangan: Sebuah Riset Campuran dengan Pendekatan Sekuensial Eksplanatif. Simposium Nasional Akuntansi XIX Lampung, 1-31.

Setiawan, L., \& Fitriany, F. (2011). Pengaruh Workload Dan Spesialisasi Auditor Terhadap

Susilawati, F. (2019). Pengaruh Profitabilitas, Likuiditas, Ukuran Perusahaan, Leverage, Free

Tri, F., Putri, S., Halim, A., \& Wulandari, R. (2015). Pengalaman Dan Kompetensi Terhadap Penyelesaian Audit. 2013, 1-14.

Widodo, W. (2015). Pengaruh Sumber Daya Manusia Terhadap Kemampuan Kerja Pegawai (Studi di Sekretariat Daerah Kabupaten Lampung Timur). Jurnal TAPIs, 11(2), 134-142. 